\title{
EFEKTIVITAS SPA KAKI DIABETIK TERHADAP SIRKULASI DARAH PERIFER PADA PASIEN DIABETES MELLITUS TIPE 2 DI WILAYAH KERJA PUSKESMAS WONOKROMO SURABAYA
}

\author{
Rahmi Affiani, Puji Astuti \\ Email : rahmi.affiani@gmail.com \\ puji@unusa.ac.id
}

\begin{abstract}
ABSTRAK
Diabetes mellitus tipe 2 paling sering terjadi dan menyebabkan komplikasi penyakit vaskuler perifer akibat penurunan sirkulasi darah perifer. Salah satu terapi untuk mencegahnya yaitu spa kaki diabetik. Tujuan dari penelitian ini adalah untuk mengetahui efektivitas spa kaki diabetik terhadap sirkulasi darah perifer. Desain penelitian ini Quasy-Experiment, dengan populasinya semua penderita diabetes mellitus tipe 2 di Wilayah Kerja Puskesmas Wonokromo Surabaya. Besar sampel 46 orang, dibagi 2 kelompok yaitu perlakuan dan kontrol masing-masing 23 orang diambil dengan teknik purposive sampling. Data dianalisa dengan uji Mann-Whitney $\alpha=0,05$. Hasil penelitian pada kelompok perlakuan sebelum dilakukan spa kaki diabetik sebagian besar $(52,2 \%)$ sirkulasi darah perifer ringan dan kelompok kontrol sebagian besar $(60,9 \%)$ juga ringan. Setelah dilakukan spa kaki, kelompok perlakuan hampir seluruhnya (91,3\%) sirkulasi darah perifer normal, sedangkan pada kelompok kontrol sebagian besar $(73,9 \%)$ tetap ringan. Analisa uji Mann-Whitney $\mathrm{P}=0,000<\alpha=0,05$, sehingga $\mathrm{H}_{0}$ ditolak artinya spa kaki diabetik efektif terhadap sirkulasi darah perifer. Semakin rutin dilakukannya spa kaki diabetik, maka sirkulasi darah perifer akan semakin baik, sehingga dapat mencegah komplikasi dari diabetes mellitus.
\end{abstract}

\section{ABSTRACT}

Diabetes mellitus type 2 is often occur and became chronic complication of vascular peripheral disease caused by decreasing peripheral blood circulation. One of therapy to improve peripheral blood circulation is diabetic foot spa. The purpose of this study is to find out the effectiveness of diabetic foot spa towards peripheral blood circulation. Design of this study is Quasy-Experiment. The population were all diabetes mellitus patients type 2 in Public Health Centre Wonokromo Surabaya. Number of sample was 46 person, divided into 2 group, that are treatment group and control group, with 23 person each group, taken by purposive sampling technique. Data analyzed by Mann-Whitney test with $\alpha=0.05$. Study results on treatment group before giving diabetic foot spa majority (52.2\%) of peripheral blood circulation in mild category and for control group mostly (60.9\%) have blood circulation in mild category as well. After the foot spa was give to the treatment group, almost entirely (91.3\%) had normal peripheral blood circulation, whereas in the control group majority (73.9\%) remain mild. Analysis of MannWhitney test $P=0.000<\alpha=0.05$, which means diabetic foot spa is effective towards blood circulation. The more frequent perform of diabetic foot spa, the better peripheral blood circulation, it can prevent complications of diabetes mellitus. 
1.

\section{Pendahuluan}

Diabetes mellitus adalah penyakit kronis progresif dengan karakteristik ketidakmampuan tubuh untuk melakukan metabolisme karbohidrat, lemak, protein, yang dapat menyebabkan gula darah meningkat (hiperglikemia) (Black \& Hawks, 2009). Diabetes mellitus tipe 2 merupakan jenis diabetes yang paling sering terjadi, mencakup sekitar $85 \%$ pasien diabetes (Greenstain \& Wood, 2010). Diabetes tipe 2 bisa menyebabkan berbagai komplikasi pada penderitanya, baik akut maupun kronik. Salah satu komplikasi kronik yang banyak terjadi adalah penyakit vaskuler perifer dan neuropati sensorik maupun motorik. Hampir $60 \%$ penderita mengalami komplikasi tersebut (Black \& Hawks, 2014).

Komplikasi penyakit vaskuler perifer dan neuropati disebabkan oleh sirkulasi darah perifer yang menurun hingga ke serabut saraf, menyebabkan penderita diabetes mudah mengalami luka gangren. Pasien DM dengan luka gangren yang berlanjut dapat berisiko amputasi seperti pendapat Greenstain dan Wood (2010) bahwa penderita diabetes mellitus berpeluang mengalami amputasi tungkai bawah 15 kali lipat daripada yang tidak menderita diabetes. Berbagai intervensi untuk mencegah atau memperlambat komplikasi tersebut dikembangkan melalui penelitian. Intervensi yang pernah diteliti antara lain senam kaki, massase kaki serta latihan rentang gerak sendi atau yang sering dikenal dengan Range of Motion (ROM) (Ika, 2010).

Salah satu jenis terapi yang baru berkembang saat ini adalah spa kaki diabetes. Spa kaki diabetes merupakan terapi untuk pasien diabetes mellitus secara menyeluruh mulai dari senam kaki, pembersihan (skin cleansing), foot mask, dan foot massage. Beberapa rumah luka sudah ada yang menerapkan spa kaki diabetes, salah satu contohnya di Rumah Luka Aska Sidoarjo. Tetapi efek terhadap peningkatan sirkulasi darah perifer belum diteliti lebih lanjut, sehingga perawat perlu mengembangkannya.

Laporan statistik dari International Diabetes Federation (IDF) menyebutkan, bahwa di tahun 2012 sudah ada lebih dari 371 juta penderita diabetes dengan tiap tahun angka kejadian diabetes naik 3\% atau bertambah 7 juta orang. Pada tahun 1995, Indonesia berada di nomor 7 sebagai negara dengan jumlah diabetes terbanyak di dunia, dan pada tahun 2025 diperkirakan Indonesia akan naik menjadi nomor 5 terbanyak. Kini dilaporkan, masyarakat kota besar seperti Jakarta dan Surabaya sudah mencapai hampir $10 \%$ penduduk yang mengidap diabetes (Tandra, 2013).

Diabetes telah menjadi penyebab kematian terbesar ke-4 di dunia. Di tahun 2012 sudah ada 4,8 juta kematian yang disebabkan langsung oleh diabetes. Pada tahun 2030 diprediksi akan ada 52 juta jiwa kematian per tahun karena penyakit tidak menular seperti diabetes mellitus seiring dengan peningkatan faktor risiko akibat perubahan gaya hidup, gangguan mental emosional dengan adanya perubahan lingkungan fisik dan perkembangan dunia yang semakin modern (Depkes RI, 2010). Komplikasi penyakit diabetes antara lain, penyakit vaskuler perifer dan neuropati diabetik, dapat menyebabkan kaki diabetes. Keadaan kaki diabetik kronis yang tidak ditangani secara tepat dapat berkembang menjadi suatu tindakan amputasi. Setiap tahun, lebih dari 1 juta orang penderita diabetes kehilangan salah satu kakinya sebagai komplikasi diabetes (FK UI, 2011). Lebih dari setengah amputasi tungkai bawah 
non traumatik berhubungan dengan perubahan karena diabetes seperti penyakit vaskuler perifer dan neuropati (Black \& Hawks, 2009). Di Wilayah Kerja Puskesmas Wonokromo sendiri terdapat $50 \%$ penderita diabetes mellitus yang mengalami luka gangren akibat sirkulasi darah perifer yang menurun. Masalah tersebut merupakan penyebab utama morbiditas, disabilitas, dan mortalitas pada seseorang yang menderita diabetes mellitus (Prabowo, 2007).

Di Wilayah Kerja Puskesmas Wonokromo Surabaya, didapatkan dari 5 orang, terdapat 1 orang dengan sedikit luka berwarna hitam di kaki kiri. Berdasarkan survey, dari 5 orang terdapat 3 orang $(60 \%)$ yang mengalami gangguan sirkulasi darah perifer sedang dan ringan yaitu dengan nilai ankle brachial index 0,8 pada responden yang memiliki luka dan 0,9 pada responden yang tidak memiliki luka. Sedangkan 2 responden lainnya (40\%) memiliki ankle brachial index 1,1 yang berarti normal.

Ketika seseorang sudah terkena diabetes mellitus, maka hal yang dapat dilakukan adalah mencegah komplikasi penyakit vaskuler perifer dan neuropati diabetik dengan memperbaiki sirkulasi darah pada kaki. Pada pasien diabetes, penurunan sirkulasi darah perifer disebabkan oleh insufisiensi insulin, sehingga terjadi gangguan-gangguan berupa penimbunan sorbitol dalam intima vaskular, hiperlipoproteinemia, dan kelainan pembekuan darah (Price \& Wilson, 2005). Pada akhirnya, gangguan pada sirkulasi darah perifer akan menyebabkan komplikasi penyakit vaskuler perifer dan neuropati diabetik. Hal tersebut jika tidak dicegah, maka akan terjadi luka gangren yang dapat berujung pada tindakan amputasi. Faktorfaktor yang dapat mempengaruhi sirkulasi darah perifer diantaranya obat-obatan, berhenti merokok, latihan, dan perawatan kaki (Black \& Hawks, 2009).
Berbagai upaya dilakukan untuk mencegah dan mengontrol terjadinya komplikasi dalam penatalaksanaan DM. Perawatan kaki adalah salah satu faktor yang dapat mempengaruhi sirkulasi darah perifer. Spa kaki diabetik merupakan serangkaian kegiatan perawatan kaki yang di dalamnya terdapat kegiatan senam kaki, pembersihan dengan air hangat, dan pemijatan (Purwanto, 2014). Kegiatan-kegiatan tersebut selain dapat melancarkan aliran darah, juga membuat pasien merasa nyaman dan rileks. Perawat dapat memberikan edukasi dan melatih keluarga untuk melakukan spa kaki di rumah, sehingga pasien diabetes tertarik dan rutin melakukan spa kaki agar dapat mencegah terjadinya luka gangren.

\section{Metodologi Penelitian}

Tujuan penelitian ini adalah untuk mengetahui efektivitas spa kaki daibetik terhadap sirkulasi darah perifer. Penelitian ini adalah penelitian kuantitatif dengan desain quasi eksperimen dengan pendekatan pre-post test with control group design. Populasi penelitian ini adalah seluruh pasien DM tipe 2 di Wilayah Kerja Puskesmas Wonokromo Surabaya. Sedangkan jumlah sampel 46 orang yang memenuhi kriteria inklusi terbagi atas 23 orang kelompok perlakuan dan 23 orang kelompok kontrol. Waktu penelitian adalah mulai bulan Maret sampai dengan April 2015 2011. Analisa data dengan SPSS 18 menggunakan uji Wilcoxon Sign Rank dengan $\alpha=0,05$.

\section{Hasil Penelitian}

Hasil penelitian menunjukkan dari 46 responden hampir seluruhnya $(76,0 \%)$ berumur 45-59 tahun yaitu sebanyak 35 orang. Berdasarkan jenis kelamin, hampir seluruhnya $(91,3 \%)$ berjenis kelamin perempuan sebanyak 42 orang. Distribusi pekerjaan menunjukkan bahwa 30 orang 
$(65,2 \%)$ memiliki pekerjaan sebagai ibu rumah tangga. Dari 46 responden, didapatkan paling sedikit sudah terkena diabetes mellitus tipe 2 selama 1 tahun dan dan paling banyak selama 7 tahun. Distribusi keteraturan terapi responden menunjukkan sebagian besar $(67,3 \%)$ teratur melaksanakan terapi diabetes yaitu sebanyak 31 orang. Berdasarkan frekuensi olahraga responden didapatkan sebagian besar $(54,3 \%)$ yaitu sebanyak 2 orang yang tidak pernah berolahraga. Sebagian besar $(63,0 \%)$ yaitu sebanyak 29 orang dari 46 responden memiliki aktivitas jalan kaki atau bersepeda kurang dari 1 jam. Sebagian besar responden $(95,6 \%)$ tidak memiliki kebiasaan merokok dan hampir seluruhnya $(82,6 \%)$ memiliki pola makan yang patuh terhadap pantangan makanan atau minuman manis maupun berlemak.

Distribusi ankle brachial index sebelum dilakukan spa kaki diabetik pada kelompok perlakuan dan kelompok kontrol dapat dilihat pada tabel 1 berikut.

Tabel 1. Distribusi ankle brachial index pada kelompok perlakuan dan kelompok kontrol sebelum dilakukan spa kaki diabetik di Wilayah Kerja Puskesmas Wonokromo Surabaya

\begin{tabular}{cccccc}
\hline No. & ABI & \multicolumn{2}{c}{$\begin{array}{c}\text { Kelompok } \\
\text { Perlakuan }\end{array}$} & \multicolumn{2}{c}{$\begin{array}{c}\text { Kelompok } \\
\text { Kontrol }\end{array}$} \\
\cline { 3 - 6 } & & $\mathrm{n}$ & $\%$ & $\mathrm{n}$ & $\%$ \\
\hline 1. & Normal & 8 & 34,8 & 5 & 21,7 \\
2. & Abnormal & 2 & 8,7 & 1 & 4,3 \\
3. & Ringan & 12 & 52,2 & 14 & 60,9 \\
4. & Sedang & 1 & 4,3 & 3 & 13,0 \\
\hline & Jumlah & 23 & 100 & 23 & 100 \\
\hline & Tabel & 1 & menunjukkan & distribusi
\end{tabular}

ankle brachial index responden kelompok perlakuan dan kelompok kontrol sebelum dilakukan spa kaki diabetik. Pada kelompok perlakuan sebagian besar $(52,2 \%)$ memiliki ABI dalam kategori ringan dan pada kelompok perlakuan sebagian besar $(60,9 \%)$ juga memiliki $\mathrm{ABI}$ dalam kategori ringan.
Tabel 2. Distribusi ankle brachial index responden pada kelompok perlakuan dan kelompok kontrol sesudah dilakukan spa kaki diabetik di Wilayah Kerja Puskesmas Wonokromo Surabaya

\begin{tabular}{cccccc}
\hline No. & ABI & \multicolumn{2}{c}{$\begin{array}{c}\text { Kelompok } \\
\text { Perlakuan }\end{array}$} & \multicolumn{2}{c}{$\begin{array}{c}\text { Kelompok } \\
\text { Kontrol }\end{array}$} \\
\cline { 3 - 6 } & & $\mathrm{n}$ & $\%$ & $\mathrm{n}$ & $\%$ \\
\hline 1. & Normal & 21 & 91,3 & 4 & 17,4 \\
2. & Abnormal & 0 & 0 & 1 & 4,3 \\
3. & Ringan & 2 & 8,7 & 17 & 73,9 \\
4. & Sedang & 0 & 0 & 1 & 4,3 \\
\hline & Jumlah & 23 & 100 & 23 & 100 \\
\hline & Tabel & 2 & menunjukkan & distribusi
\end{tabular}

ankle brachial index pada kelompok perlakuan dan kelompok kontrol sesudah dilakukan spa kaki diabetik. Pada kelompok perlakuan hampir seluruhnya $(91,3 \%)$ memiliki ABI dalam kategori normal setelah dilakukan spa kaki diabetik, sedangkan pada kelompok kontrol sebagian besar $(73,9 \%)$ memiliki ABI ringan.

Tabel 3. Distribusi perbedaan ankle brachial index sebelum dan sesudah dilakukan spa kaki diabetik pada kelompok perlakuan dan perbedaan ankle brachial index sebelum dan sesudah dilakukan spa kaki diabetik pada kelompok perlakuan

\begin{tabular}{|c|c|c|c|c|c|c|c|c|c|}
\hline \multirow{3}{*}{ No } & \multirow{3}{*}{$\mathrm{ABI}$} & \multicolumn{4}{|c|}{ Kelompok Perlakuan } & \multicolumn{4}{|c|}{ Kelompok Kontrol } \\
\hline & & \multicolumn{2}{|c|}{ Pre } & \multicolumn{2}{|c|}{ Post } & \multicolumn{2}{|c|}{ Pre } & \multicolumn{2}{|c|}{ Post } \\
\hline & & $\mathrm{N}$ & $\%$ & $\mathrm{n}$ & $\%$ & $\mathrm{n}$ & $\%$ & $\mathrm{n}$ & $\%$ \\
\hline 1. & Normal & 8 & 34,8 & 21 & 91,3 & 5 & 31,7 & 4 & 17,4 \\
\hline 2. & Abnormal & 2 & 8,7 & 0 & 0 & 1 & 4,3 & 1 & 4,3 \\
\hline 3. & Ringan & 12 & 52,2 & 2 & 8,7 & 14 & 60,9 & 17 & 73,9 \\
\hline 4. & Sedang & 1 & 4,3 & 0 & 0 & 3 & 13,0 & 1 & 4,3 \\
\hline & Jumlah & 23 & 100 & 23 & 100 & 23 & 100 & 23 & 100 \\
\hline $\mathrm{Pv}$ & e Wilcoxon & \multicolumn{4}{|c|}{$0,000^{*}$} & \multicolumn{4}{|c|}{1.000} \\
\hline \multicolumn{2}{|c|}{$\begin{array}{c}\text { P value Mann- } \\
\text { Whitney }\end{array}$} & & & & & \multicolumn{2}{|c|}{0,000} & & \\
\hline
\end{tabular}

Tabel 3 menunjukkan bahwa dari 23 responden kelompok perlakuan sebagian besar $(52,2 \%)$ memiliki ABI dalam kategori ringan sebelum dilakukan tindakan spa kaki diabetik, dan setelah dilakukan spa kaki diabetik, hampir seluruhnya $(91,3 \%)$ memiliki ABI dalam kategori normal. Pada kelompok kontrol didapatkan sebagain besar $(60,9 \%)$ memiliki ABI dalam kategori ringan sebelum dilakukan tindakan spa kaki 
diabetik, setelah pelaksanaan spa kaki diabetik didapatkan sebagian besar $(73,9 \%)$ memiliki ABI dalam kategori ringan.

Berdasarkan uji Wilcoxon Sign Rank pada kelompok perlakuan didapatkan nilai $\mathrm{P}$ $=0,000$ dan nilai $\alpha=0,05$ berarti $\mathrm{P}<\alpha$ maka $\mathrm{H}_{0}$ ditolak, artinya spa kaki diabetik efektif terhadap sirkulasi darah perifer pada pasien diabetes mellitus tipe 2 di Wilayah Kerja Puskesmas Wonokromo Surabaya. Sedangkan pada kelompok kontrol didapatkan nilai $\mathrm{P}=1.000$ dan nilai $\alpha=0,05$ berarti $\mathrm{P}>\alpha$ maka $\mathrm{H}_{0}$ diterima, yang berarti tidak ada pengaruh pada sirkulasi darah pasien kelompok kontrol karena tidak diberikan tindakan spa kaki diabetik.

Berdasarkan uji Mann-Whitney untuk membedakan hasil post spa kaki diabetik pada kelompok perlakuan dan kelompok kontrol didapatkan nilai $\mathrm{P}=0,000$ dan nilai $\alpha=0,05$ berarti $\mathrm{P}<\alpha$, artinya bahwa ada perbedaan yang bermakna antara kelompok perlakuan dan kelompok kontrol setelah tindakan spa kaki diabetik.

\section{Pembahasan}

\subsection{Sirkulasi darah perifer sebelum} tindakan spa kaki diabetik (pre test)

Hasil penelitian menunjukkan bahwa sebelum dilakukan spa kaki diabetik didapatkan dari 23 responden kelompok perlakuan sebagian besar $(52,5 \%)$ memiliki sirkulasi darah perifer dalam kategori ringan. Sedangkan pada kelompok kontrol sebagian besar $(60,9 \%)$ memiliki sirkulasi darah perifer dalam kategori ringan. Sirkulasi darah perifer yang dapat diukur dengan nilai ankle brachial index menunjukkan risiko seseorang dapat mengalami luka gangren atau tidak. Pada pasien diabetes, bila kadar glukosa darah tidak terkontrol, baik dalam waktu yang lama pada diabetes mellitus, pembuluh darah di berbagai jaringan di seluruh tubuh mulai mengalami gangguan fungsi dan perubahan struktur yang berakibat ketidakcukupan suplai darah ke jaringan. Hal tersebut selanjutnya akan meningkatkan risiko untuk terkena luka gangren (Guyton \& Hall, 2014). Gangguan pada sirkulasi darah perifer akan menyebabkan komplikasi penyakit vaskuler perifer dan neuropati diabetik pada penderita diabetes mellitus.

Umur adalah salah satu faktor yang dapat mempengaruhi sirkulasi darah perifer. Lazimnya penyakit vaskuler perifer banyak dialami pada orang yang lebih tua (Black \& Hawks, 2014). Berdasarkan tabel 5.1 menunjukkan bahwa dari 23 responden kelompok perlakuan didapatkan hampir seluruhnya $(78,3 \%)$ berumur $45-59$ tahun, sementara dari 23 responden kelompok kontrol sebagian besar $(73,9 \%)$ berumur $45-$ 59 tahun. Kejadian diabetes mellitus tipe 2 mencapai puncaknya pada usia 40-70 tahun, hal ini disebabkan karena kelompok usia diatas 40 tahun mempunyai risiko lebih tinggi terkena DM akibat menurunnya toleransi glukosa yang berhubungan dengan berkurangnya sensitivitas sel perifer terhadap efek insulin. Hal ini sesuai dengan teori Guyton \& Hall (2014) resistensi insulin pada penderita Diabetes Mellitus (DM) tipe 2 cenderung meningkat pada usia diatas 30 tahun. Hal tersebut disebabkan karena berkurangnya sensitivitas jaringan-jaringan tubuh terhadap insulin. Resistensi terhadap insulin menyebabkan kerentanan terhadap penyakit vaskuler perifer pada pasien diabetes mellitus yang berakibat terjadinya penurunan terhadap sirkulasi darah perifer. Selain itu semakin tua usia seseorang maka sirkulasi darahnya pun akan semakin menurun (Tandra, 2008).

Selain umur, jenis kelamin juga berpengaruh terhadap sirkulasi darah perifer. Berdasarkan hasil penelitian didapatkan dari 23 responden kelompok perlakuan hampir seluruhnya $(91,3 \%)$ berjenis kelamin perempuan, dan dari 23 responden 
kelompok kontrol hampir seluruhnya $(91,3 \%)$ juga berjenis kelamin perempuan. Hal tersebut sesuai dengan teori Guyton \& Hall (2014) bahwa 6\% perempuan mengalami sindrom ovarium polikistik (PCOS), menyebabkan peningkatan produksi androgen di ovarium dan resistensi insulin serta merupakan salah satu kelainan endokrin tersering pada perempuan. Meskipun patogenesis PCOS masih belum jelas, resistensi insulin dan hiperinsulinemia sering dijumpai, kira-kira sebanyak $80 \%$ perempuan yang mengalami sindrom ini. Meskipun presentase menunjukkan angka yang kecil pada wanita untuk terjadinya PCOS, namun hal ini dapat berpengaruh dan menyebabkan wanita lebih berisiko terkena gangguan sirkulasi darah.

Distribusi responden berdasarkan pekerjaan menunjukkan bahwa dari 23 responden kelompok perlakuan didapatkan sebagian besar $(65,2 \%)$ memiliki pekerjaan sebagai ibu rumah tangga dan dari 23 responden kelompok kontrol sebagian besar $(65,2 \%)$ juga memiliki pekerjaan sebagai ibu rumah tangga. Pekerjaan seseorang berhubungan dengan aktivitasnya seharihari, dimana aktivitas mempengaruhi sirkulasi darah seseorang (Black \& Hawks, 2014). Ibu rumah tangga belum tentu memiliki aktivitas yang rendah seperti mencuci, memasak, menyapu dan lain sebagainya.

Hasil penelitian pada data umum menunjukkan bahwa sebagian besar responden $(69,6 \%)$ pada kelompok perlakuan dan sebagian besar responden $(56,5 \%)$ pada kelompok kontrol melakukan aktivitas jalan kaki atau bersepeda $\leq 1$ jam, selain itu, kebiasaan olahraga responden. Pada kelompok perlakuan sebagian besar $(56,5 \%)$ tidak pernah berolahraga, dan dari 23 responden kelompok kontrol sebagian besar $(52,5 \%)$ juga didapatkan tidak pernah berolahraga. Hal ini berarti bahwa pekerjaan tidak mutlak mempengaruhi sirkulasi darah seseorang, bergantung pada aktivitas yang dijalani di dalam pekerjaannya tersebut.

\subsection{Sirkulasi darah perifer sesudah} tindakan spa kaki diabetik (post test)

Sirkulasi darah perifer pada pasien diabetes mellitus tipe 2 di Wilayah kerja Puskesmas Wonokromo Surabaya setelah diberikan tindakan spa kaki diabetik mengalami perubahan, terutama pada kelompok perlakuan. Berdasarkan tabel 2 menunjukkan bahwa dari 23 responden kelompok perlakuan setelah dilakukan spa kaki diabetik hampir seluruhnya $(91,3 \%)$ mengalami peningkatan sirkulasi darah perifer menjadi kategori normal. Sedangkan dari 23 responden kelompok kontrol sebagian besar $(73,9 \%)$ memiliki sirkulasi darah perifer dalam kategori ringan. Pengukuran sirkulasi darah perifer dengan ankle brachial index dikategorikan menjadi 5 yaitu kategori normal dengan nilai $\mathrm{ABI}$ $\geq 1,0$, abnormal $(\geq 1,4)$, ringan $(\leq 0,9)$, sedang $(\leq 0,6-0,8)$, dan berat $(\leq 0,5)$. Normal berarti pada pembuluh darah tidak terjadi suatu gangguan, sedangkan ringan hingga berat menunjukkan adanya aterosklerosis, dan abnormal berarti sudah terjadi penyempitan pada pembuluh darah di berbagai tempat di dalam tubuh. Terjadinya aterosklerosis pada pembuluh darah pada pasien diabetes mellitus ini disebabkan karena adanya gangguan-gangguan berupa penimbunan sorbitol dalam intima vaskular, hiperlipoproteinemia, dan kelainan pembekuan darah seperti teori yang dikemukakan oleh Price \& Wilson (2005).

Berdasarkan data umum mengenai umur, jenis kelamin, pekerjaan, lamanya terkena diabetes, keteraturan terapi, frekuensi olahraga, aktivitas jalan kaki atau bersepeda, kebiasaan merokok, dan pola makan antara kelompok perlakuan dan 
kelompok kontrol menunjukkan persentase yang hampir sama rata. Setelah tindakan spa kaki diabetik selama 5 hari menunjukkan peningkatan terhadap sirkulasi darah responden pada kelompok kontrol, sedangkan pada kelompok kontrol sebagian besar $(73,9 \%)$ sirkulasi darah perifer masih berada dalam kategori ringan. Hal ini berarti bahwa tindakan spa kaki diabetik yang diberikan pada kelompok perlakuan dapat meningkatkan sirkulasi darah perifer dalam mencegah komplikasi kronis diabetes mellitus. Spa kaki diabetik merupakan perawatan kaki secara menyeluruh, dimana perawatan kaki adalah salah satu faktor yang mempengaruhi sirkulasi darah perifer seperti teori yang dikemukakakn oleh Black and Hawks (2014).

4.3 Perbedaan sirkulasi darah perifer pre-post spa kaki diabetik pada kelompok perlakuan dan perbedaan sirkulasi darah perifer pre-post spa kaki diabetik pada kelompok kontrol

Pada tabel 3 menunjukkan perbedaan pre dan post test pada kelompok perlakuan dan kelompok kontrol. Pada kelompok perlakuan setelah dilakukan spa kaki diabetik terjadi perubahan nilai ankle brachial index dari ringan menjadi normal meskipun sebagian kecil (8,7\%) masih memiliki ABI dalam kategori ringan. Hal tersebut dikarenakan ada responden yang merokok, tidak teraturnya menjalankan terapi diabetes, dan tidak menjaga pola makannya terhadap makanan manis dan berlemak. Menurut Black and Hawks (2014), rokok adalah vasokonstriktor kuat sehingga mengganggu aliran darah ke ekstremitas. Hal tersebut membuat seorang perokok rentan mengalami penurunan sirkulasi darah perifer. Pola makan yang dimaksud adalah tidak mengontrol makanan dan minuman yang mengandung gula tinggi serta makanan-makanan berlemak. Makanan dan minuman dengan kadar gula tinggi tentu akan menyebabkan kadar gula darah meningkat, sehingga orang dengan pola makan yang tidak terkontrol lebih rentan terhadap gangguan pada sirkulasi darahnya. Seperti pendapat dari Helmawati (2014) yang menyatakan bahwa pola makan yang tidak seimbang erat kaitannya dengan diabetes mellitus.

Spa kaki diabetik terdiri dari berbagai macam kegiatan yaitu senam kaki diabetik sebelum pelaksanaan spa kaki, skin cleansing yaitu pembersihan dengan menggunakan sabun mandi bayi yang lembut dan ringan, pedicure yaitu pemotongan dan pengikisan kuku jika responden memiliki kuku yang sedang panjang, foot mask yaitu tindakan memberikan lulur dengan tujuan untuk membersihkan sel-sel kulit mati, tetapi untuk tindakan ini tidak dilakukan setiap hari agar lapisan kulit tidak semakin menipis, dan terakhir adalah foot massage yaitu pemijatan superfisial pada kaki untuk meningkatkan sirkulasi darah. Spa kaki diabetik ini dilakukan \pm 30 menit selama 5 hari berturut-turut pada kelompok perlakuan. Kegiatan-kegiatan di dalam spa kaki diabetik memberikan pengaruh terhadap sirkulasi darah perifer secara menyeluruh. Kegiatan-kegiatan tersebut selain dapat melancarkan aliran darah, juga membuat pasien merasa nyaman dan rileks.

Menurut Andriyanto et. al. (2013), senam kaki efektif terhadap tingkat sensitivitas kaki. Rangsangan yang diberikan dari sesi refleksiologi senam kaki akan membuat rileks dan melancarkan peredaran darah. Lancarnya peredaran darah tersebut memungkinkan darah mengantar lebih banyak oksigen dan gizi ke sel-sel tubuh, sekaligus membawa lebih banyak racun untuk dikeluarkan. Sehingga aliran darah yang lancar akan meningkatkan sensasi proteksi pada kulit. Pada saat kegiatan skin cleansing (pembersihan), kaki 
klien direndam dengan menggunakan air hangat. Air hangat bermanfaat untuk memperlancar sirkulasi darah, karena air hangat dapat membuat vasodilatasi pada pembuluh darah (Susanti, 2012).

Selain senam kaki dan perendaman dengan air hangat, kegiatan pijat kaki didalam spa kaki diabetik juga mempengaruhi sirkulasi darah perifer. Menurut Badawi (2009), foot massage atau pijat kaki dapat mempengaruhi hormon tubuh, yaitu dapat meningkatkan sekresi endorfin. Endorfin memiliki efek narkotika alami yaitu mengurangi rasa sakit dan meningkatkan kegembiraan. Endorfin menyebabkan vasodilatasi pembuluh darah sehingga dapat meningkatkan sirkulasi darah perifer.

Tabel 3 juga menunjukkan distribusi nilai ankle brachial index pada kelompok kontrol antara sebelum dan sesudah tindakan spa kaki diabetik. Berdasarkan tabel 3 menunjukkan bahwa dari 23 responden kelompok kontrol sebagian besar $(60,9 \%)$ memiliki ABI dalam kategori ringan sebelum dilakukan tindakan spa kaki diabetik, dan setelah pelaksanaan spa kaki diabetik, sebagian besar $(73,9 \%)$ juga memiliki ABI dalam kategori ringan. Hal ini menunjukkan bahwa tidak ada perbedaan yang bermakna pada nilai ankle brachial index kelompok kontrol. Pada kelompok kontrol tidak dilakukan tindakan spa kaki diabetik seperti pada kelompok perlakuan. Selama 5 hari berturut-turut, responden pada kelompok kontrol hanya melakukan kegiatan sehari-hari seperti biasa dan samasama menjalani pengobatan diabetes. Meskipun ada 2 responden pada kelompok kontrol yang memiliki ABI sedang meningkat menjadi ringan, namun berdasarkan aktivitas didapatkan dari 23 responden kelompok kontrol sebagian besar $(56,5 \%)$ memiliki aktivitas jalan kaki atau bersepeda $\leq 1$ jam dan sebagian besar $(52,5 \%)$ juga didapatkan tidak pernah berolahraga.

\subsection{Efektivitas spa kaki diabetik terhadap sirkulasi darah perifer pada pasien diabetes mellitus tipe 2 di Wilayah Kerja Puskesmas Wonokromo Surabaya}

Efektivitas spa kaki diabetik terhadap sirkulasi darah perifer pada pasien diabetes mellitus tipe 2 di Wilayah Kerja Puskesmas Wonokromo Surabaya dapat dilihat pada tabel 3 yang menunjukkan bahwa dari 23 kelompok perlakuan sesudah diberikan spa kaki diabetik hampir seluruhnya $(91,3 \%)$ memiliki ankle brachial index normal. Berdasarkan uji Wilcoxon Sign Rank didapatkan nilai $\mathrm{P}$ adalah 0,000 dan nilai $\alpha=0,05$, berarti $\mathrm{P}<\alpha$ maka $\mathrm{H}_{0}$ ditolak, artinya ada efektivitas spa kaki diabetik terhadap sirkulasi darah perifer pada pasien diabetes mellitus tipe 2 di Wilayah Kerja Puskesmas Wonokromo Surabaya.

Berdasarkan data diatas dapat disimpulkan bahwa spa kaki diabetik efektif terhadap sirkulasi darah perifer. Senam kaki merupakan salah satu kegiatan latihan di dalam spa kaki untuk melancarkan sirkulasi darah perifer, didalamnya terdapat beberapa gerakan untuk melatih otot-otot kaki. Menurut pendapat Sari (2012) bahwa terdapat manfaat latihan untuk penderita diabetes yaitu mengontrol gula darah dengan menurunkan resistensi insulin yang akan meningkatkan sensitivitas insulin di otototot dan jaringan lain sehingga kadar gula mengalami perbaikan. Resistensi insulin itu sendiri dapat mengakibatkan kerentanan terhadap penyakit vaskuler perifer, sehingga kegiatan senam kaki sangat bermanfaat didalam spa kaki diabetik.

Spa kaki diabetik merupakan kegiatan perawatan kaki yang diperlukan pasien diabetes secara menyeluruh untuk 
mencegah timbulnya luka gangren. Seperti pendapat dari Helmawati (2014) bahwa pencegahan timbulnya kaki diabetik mutlak diperlukan. Prinsip pencegahan kaki diabetes adalah menghindari terjadinya luka dan terus berupaya mengontrol keadaan gula darah. Pada spa kaki diabetik selain kegiatan senam kaki, kegiatan pembersihan (skin cleansing) dan pedicure atau pemotongan kuku dimaksudkan untuk mencegah kuku yang terlalu panjang dan masuk ke dalam sehingga dapat melukai kaki. Kegiatan foot massage merupakan rangkaian kegiatan spa kaki diabetik yang tidak kalah penting selain kegiatan senam kaki, skin cleansing, pedicure, dan foot mask. Dalam pijat kaki terdapat titik-titik tertentu yang menghubungkan ke organ pankreas untuk merangsang produksi insulin. Seperti pendapat Gala (2009) bahwa pemijatan di area telapak kaki kiri dapat merangsang pankreas untuk memproduksi insulin. Pijat kaki juga sangat disenangi oleh banyak orang karena selain bermanfaat untuk sirkulasi darah, namun memberikan efek relaksasi.

\subsection{Keterbatasan Penelitian}

Dalam penelitian ini, peneliti memiliki keterbatasan tidak dapat mengontrol bagaimana pola makan responden, aktivitas sehari-hari seperti berjalan kaki atau bersepeda, maupun kegiatan olahraganya. Hal tersebut dikarenakan penelitian dilakukan di komunitas.

\section{Kesimpulan}

Terdapat efektivitas spa kaki diabetik terhadap sirkulasi darah perifer dan terdapat perbedaan yang bermakna antara kelompok perlakuan dan kelompok kontrol. Semakin rutin dilakukan spa kaki diabetik pada pasien diabetes mellitus, maka akan semakin baik pula sirkulasi darah perifernya dalam mencegah komplikasi diabetes mellitus.
Referensi:

1. Baradero, Mary dkk. 2009. Seri Asuhan Keperawatan Klien Gangguan Endokrin. Jakarta: EGC

2. Black, M. Joyce dan Jane Hokanson Hawks. 2009. Medical-Surgical Nursing - Clinical Management for Positive Outcomes. Missouri: Elsevier

3. Black, M. Joyce dan Jane Hokanson Hawks. 2014. Keperawatan Medikal Bedah - Manajemen Klinis untuk Hasil yang Diharapkan Edisi Bahasa Indonesia. 2014. Singapura: Elsevier

4. Dharma, Kelana Kusama. 2011. Metodologi Penelitian Keperawatan Panduan Melaksanakan dan Menerapkan Hasil Penelitian. Jakarta: Trans Info Media

5. Endriyanto, Eko dkk. 2013. Efektifitas Senam Kaki Diabetes Mellitus dengan Koran terhadap Tingkat Sensitivitas Kaki pada Pasien DM Tipe 2. www.googlescholar.com, diunduh pada tanggal 20 Februari 2015

6. Fakultas Kedokteran Universitas Indonesia. 2011. Penatalaksanaan Diabetes Melitus Terpadu - Panduan Penatalaksanaan Diabetes Melitus bagi Dokter dan Edukator. Jakarta: Badan Penerbit FK UI

7. Fitria D.A, Lailatul. 2011. Spa sebagai Daya Dukung Wisata Kesehatan di Solo (Taman Sari Royal Heritage Spa). www.googlescholar.com, diunduh tanggal 31 Januari 2015

8. Greenstain, Ben dan Diana Wood. 2010. At a Glance Sistem Endokrin Edisi Kedua. Jakarta: Erlangga

9. Guyton dan Hall. 2014. Buku Ajar Fisiologi Kedokteran Edisi Keduabelas. Singapore: Saunders Elsevier

10. Harmaya dkk. 2014. Pengaruh Masase Kaki terhadap Sensasi Proteksi pada Kaki Pasien Diabetes Melitus Tipe II 
dengan Diabetic Peripheral Neuropathy. www.googlescholar.com, diunduh pada tanggal 25 Januari 2015

11. Harefa, Karnirius dan Artika Sari. 2011. Pengaruh Senam Kaki terhadap Sirkulasi Darah kaki pada Pasien Diabetes Melitus di Ruang Penyakit Dalam RSU Dr. Pirngadi Medan. www.googlescholar.com, diunduh 19 Januari 2015

12. Hasdianah. 2012. Mengenal Diabetes Mellitus pada Orang Dewasa dan Anakanak dengan Solusi Herbal. Yogyakarta: Nuha Medika

13. Helmawati, Triana. 2014. Hidup Sehat Tanpa Diabetes. Jakarta: NOTEBOOK

14. Iskandar, Munadjat. 2010. Health Triad (Body, Mind, and System). Jakarta: Elex Media Komputindo

15. Kementrian Kesehatan Republik Indonesia. 2012. Buletin Jendela Data dan Informasi. www.depkes.go.id, diunduh pada tanggal 21 Januari 2015

16. Laksmi dkk. 2013. Pengaruh Foot Massage terhadap Ankle Brachial Index (ABI) Pada Pasien DM Tipe 2 Di Puskesmas II Denpasar Barat. www.googlescholar.com, diunduh 19 Januari 2015

17. Mahendra dan Ade Tobing. 2008. Care Your Self Diabetes Mellitus. Jakarta: Penebar Plus

18. Notoadmodjo, Soekidjo. 2012. Metodologi Penelitian Kesehatan. Jakarta: Rineka Cipta

19. Nursalam. 2008. Konsep dan Penerapan Metodologi Penelitian Ilmu Keperawatan Edisi 2. Jakarta: Salemba Medika

20. Padila. 2012. Buku Ajar Keperawatan Medikal Bedah. Yogyakarta: Nuha Medika

21. Price, A. Sylvia dan Lorraine M. Wilson. 2005. Patofisiologi Konsep Klinis
Proses-proses Penyakit Edisi 6. Jakarta: EGC

22. Purwanto, Budhi. 2014. Spa Kaki Diabetesi (Layanana Estetika pada Kaki Penderita Kencing Manis). Yogyakarta: Gava Medika

23. Riyadi, Eka Aditya. 2013. Perbandingan Nilai Angkle Brachial Index pada Kombinasi Terapi Ceragem dan Senam Kaki Diabetik dengan Senam Kaki Diabetik Standar pada Penderita Diabetes Mellitus Tipe II di Puskesmas Cilacap Utara I. http://keperawatan.unsoed.ac.id, diunduh pada tanggal 20 Januari 2015

24. Setyoadi dan Kushariyadi. 2011. Terapi Modalitas Keperawatan pada Klien Psikogeriatrik. Jakarta: Salemba Medika

25. Suari dkk. 2015. Pengaruh Pemberian Active Lower ROM terhadap Perubahan Nilai Ankle Brachial Index Pasien DM Tipe 2 di Wilayah Puskesmas II Denpasar Barat. www.googlescholar.com, diunduh pada tanggal 5 Februari 2015

26. Sulistiari, Dwi Anis. 2013. Pengaruh Pendidikan Kesehatan Perawatan Kaki terhadap Kepatuhan Pasien Diabetes Mellitus Tipe 2 dalam Melakukan Perawatan Kaki di Wilayah Kerja Puskesmas Jenggawah Kabupaten Jember. $\quad$ www.googlescholar.com, diunduh pada tanggal 25 januari 2015

27. Susanti, Nurlaili. 2012. Efektifitas Kompres Dingin dan Hangat pada Penatalaksanan Demam. www.googlescholar.com, diunduh pada tanggal 20 Februari 2015

28. Tandra, Hans. 2013. Life Healthy with Diabetes - Diabetes Mengapa \& Bagaimana. Yogyakarta: Rapha Publishing 